21. Richni zvity Natskomfinposluh [Electronic resource] // $\mathrm{Na}$ tional Commission for State Regulation of Financial Services Markets in Ukraine. - Available at: \www/URL: http://nfp. gov.ua/content/rzviti-nackomfinposlug.html

\section{ОПРЕДЕЛЕНИЕ ПРИОРИТЕТНЫХ ГРУПЛ ИНДИКАТОРОВ ДЛЯ ИДЕНТИФИКАЦИИ УГРОЗ ФИНАНСОВОЙ БЕЗОПАСНОСТИ CTPAXOBOTO PЫHKA}

Определены группы индикаторов для идентификации угроз при оценке финансовой безопасности страхового рынка основываясь на отчетах о состоянии и развитии страхового рынка, данных о регулировании и надзору, подготовленные национальным регулятором, а также с учетом показателей финан- совой результативности, интенсивности и эффективности государственного регулирования и надзора. С использованием метода анализа иерархий определены приоритетные группы индикаторов для идентификации угроз финансовой безопасности страхового рынка.

Ключевыг слова: национальный страховой рынок, группы индикаторов, угрозы финансовой безопасности, регуляторное влияние, пруденциальный надзор.

Achkasova Svitlana, PhD, Associate Professor, Department of Financial Services Management, Simon Kuznets Kharkiv National University of Economics, Ukraine, e-mail: svet_achk@meta.ua, ORCID: http://orcid.org/0000-0001-7233-0189

Samoilyk Iu.

\title{
IMPROVEMENT OF SCIENTIFIC CONCEPTUAL PARADIGMS OF MARKET DEVELOPMENT IN CONDITIONS OF ECONOMIC GLOBALIZATION
}

Побудовано конщептуальну модель міжгалузевих наукових зв'язків категорії «ринок», для побудови якої використано чотири основних підходи: політекономічний, управлінський, маркетингово-логістичний та підхід з точки зору інтелектуальної власності та бізнесу. Виявлено відмінності між термінами «міжнародний», «світовий», «елобальний», «зовнішньоекономічний». Побудовано модель структури чинників, що впливають на ринкове середовище.

Ключові слова: міжгалузеві наукові зв'язки, концептуальна модель, глобалізація економіки, чинники ринкового середовища.

\section{Introduction}

The dominance of market economy in global trends and their relentless dynamic distribution is the main feature of the contemporary economy. The market economy is a form of economic relations in which the products and services are produced in national economic system designed primarily for sales and take the form of commodities. Basic features of a market economy are as follows: the advantage of private property, freedom of establishment and freedom of consumer choice, limited role of government in regulating market processes; pure competition over dominance of monopolistic, developed antitrust regulation; opportunistic pricing, marketing management system focused on the consumer. The phenomenon of globalization influences the market development significantly in modern conditions. Each state is an integral element of the global economic space; it does not depend on of the level of development, specialization, availability of resources, political system. However, each country has a role in the global environment. Status of market participants is defined primarily by the level of economic development, effective governance, the presence of international competitive advantages, efficiency of integration ties. The impact of globalization on domestic economies can be both positive and negative, evidenced by historical experience of international globalization. As a result, active dynamics of bipolar tendencies can be traced in market environment. These trends depend on the level of the state, its economic policy, sustainability, place in the international division of labor and cooperation.

Global economic environment allows identifying leaders of markets and countries that are the only consumers of product. However, new trends are emerging constantly in terms of the variability of environment. It influence on the global redistribution of markets, the emergence of new leaders, changing consumer culture, technology and innovation activity. Thus, there is a need to identify new features and trends in markets in a globalized economy that determines the relevance of research in this area.

\section{The object of research and its technological audit}

Object is a global market environment, the conceptual gist of market, relationships in a market system. Market development in a globalizing economy is multilevel and multivector. The essence of the concept of «market» gets new content in a globalized economy. Elucidation of the new characteristics of the market needs to identify new features of national markets. Political economy approach, management approach, marketing and logistic approach and the approach in terms of intellectual property and business to determine the essence of the concept of «market» will be considered in the article. Different approaches to the construction market model must be investigated. Classification of markets must be improved. A many factors impact on the formation of a system market. These factors must be exploring. 


\section{The aim and objectives of research}

The aim of the research is the development of conceptual approaches to identify the essence of the category «market» and the identifying features of the market in a globalized economy. Objectives have been formulated to achieve this goal:

1. Creating a conceptual model of intersectoral scientific relations of category «market».

2. Improving the interpretation of the category of «market».

3. Identification of the differences between the terms: «international», «world», «global», «foreign trade».

4. Creating a model of structure of the factors influencing the market environment.

\section{Research of existing solutions of the problem}

Conceptual bases of functioning of the market, the formation of its principles and functions are inherent to [1-3]. These economists have formulated a definition «market» in his works to characterize the process of sale of goods, but this concept acquires a different meaning in modern terms. The problem of the development of market has been caused considerable interest among scholars with the development of commodity-money relations. The issue became especially important during the organizational and economic adaptation to market conditions in Ukraine. An important contribution has been made by scientists in system of modern market theory. Scientific papers [4-6] are devoted to current theories of political economy of the market. The classical approach to the development of conceptual frameworks market has been traceable in these works. However, current conditions have need of extension of the classical approach, it must be complemented by global aspect of the market. Globalization approach can be seen in the works [7-10]. Scientists consider the market on a global scale, but it does not take into account the industry, especially the development of the market. Some elements of the market are considered in the works [11, 12]. In particular, work [11] is dedicated to the issues of formation of market infrastructure globally. Article [12] describes the features of the formation and evaluation of enterprise competitiveness in the market environment. Scientific papers [13, 14] are deserved attention. They are devoted to aspects of the industry market, including especially the development of agri-food market and organic products are considered in these works. In general, a significant number of works on the development of the market exists in current literature, but general comprehensive approach to identify the conceptual nature of this category of «market» is non-available. This underlines the relevance of research in this area.

Market in the textbook «Economics» is being considered as «institution or mechanism that brings together buyers (representatives of demand) and sellers (suppliers) of certain goods and services» [2]. Current political economy approaches to interpret the essence of the concept of «market» are quite thorough [15]. Some authors consider «that the definition «market» is associated primarily to the economic relations of producers and consumers regarding the exchange of social product [6]. The scientists formed a fundamental copyright concept of operation and market development in the current economic conditions, but the need to supplement existing development of new relevant research market paradigm occurs due to the dynamism and permanency of environment management, the emergence of new trends, structural changes, instruments and methods of regulating the existing mechanisms of doing business.

\section{Methods of research}

The methodological approach of research is being based on dialectical approach to the formation of new market paradigms and building of the conceptual models. Deduction method is being used also in the study, which is to interchange from the general to the conceptual models of partial elements of these models. Monographic method is being used to compile scientific experience. Methods of comparison, analysis and synthesis are being used to form the authors' models.

\section{Research results}

Generalizations by authors to determine the essence of the category of «market» have been considered. Depth studies of scientific thought on this issue have been made in retrospect. We determined that market is the multicategory, four main approaches should be used for understanding this category. Each of these approaches should be structured and divided into blocks:

1) political economy approach (economics, social economics, micro, macroeconomics, law, government regulation of the economy);

2) management paradigm (in its variations of: management potential, strategic, industrial, environmental management);

3) marketing and logistics approach (marketing, logistics, information);

4) approach in terms of intellectual property and business (intellectual property, business potential).

These approaches are interrelated and form a systematic definition «market», combining cross-industry scientific relations (Fig. 1).

Consequently, we consider that the market is a system of economic relations between market actors on buying and selling market objects in a defined territory for a certain period of time provided free opportunistic pricing, limited government regulation, freedom of choice and free disposal traded under limited resources under the influence of economic globalization.

This interpretation of the category of «market» requires extended comments. The territory may be limited physically, spatially, or can be virtually unlimited.

It depends on the scale of the market, its subjects and objects. For example, buying and selling can be in place in well-defined territory, which has a special meaning for these operations (trading market, shop, and mall).

It can be Internet store. A special place does not exist in such conditions, but such activities may be limited by the seller geographically, depending on the chosen strategy development and capture market. Moreover, when it comes to buying and selling goods and services in international and global scale, we can talk about this territorial unlimited market. Time limits define the speed of the market, its dynamism, strength, intensity or extensiveness of commodity-money relations. 


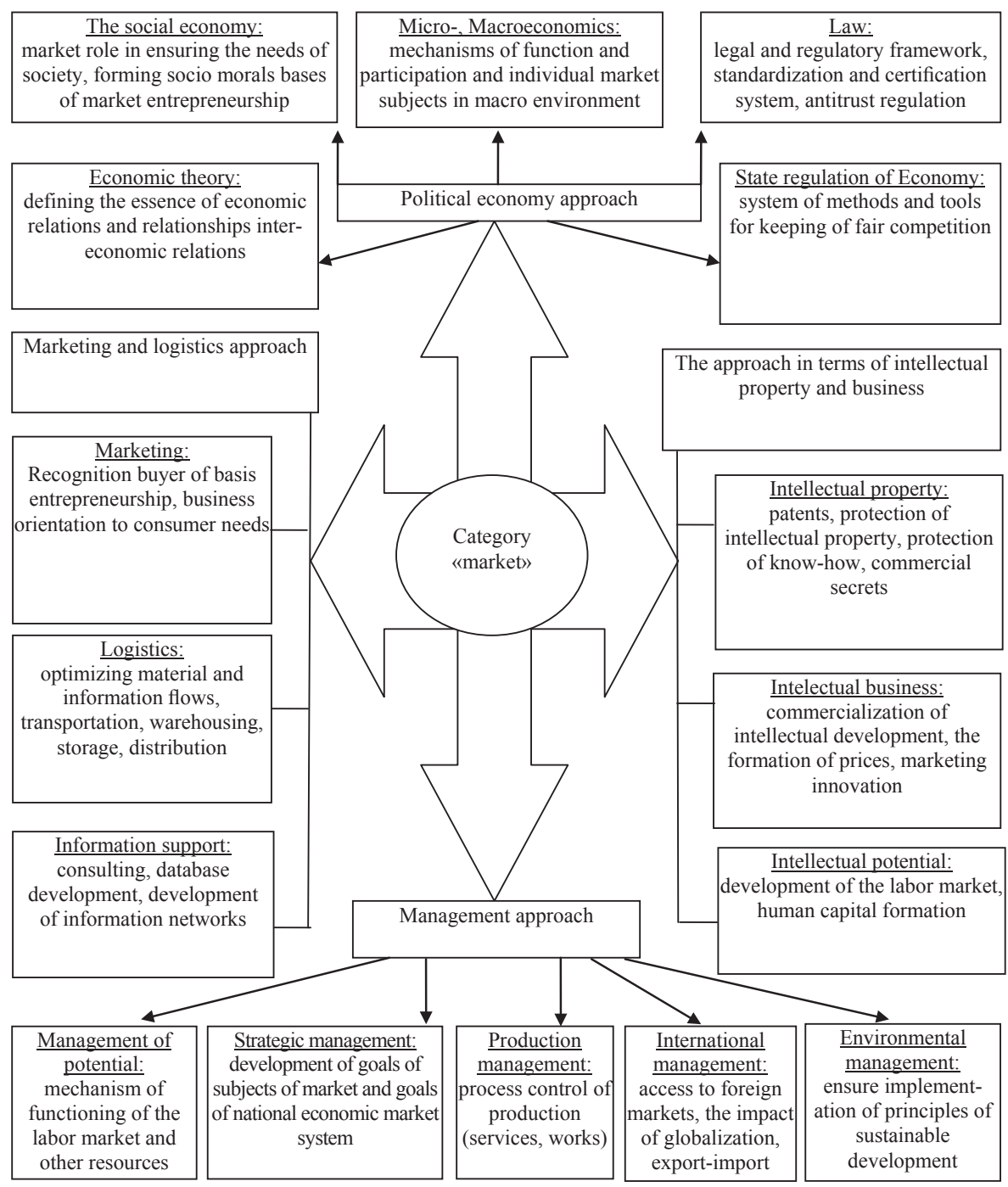

Fig. 1. The concept of intersectoral scientific relations of category «market» (developed by the author)

ment that functions are interrelated system of market economy countries. Thus, globalization of markets is the foundation of economic globalization. The question of expanding the boundaries of markets is becoming more urgent. Discussion on the feasibility of the use of identical concepts of «global market», «world market», «global economy» and «world economy» arises.

The world market is a set of national markets, combined together by worldwide economic relations on the basis of the international division of labor, specialization, cooperation, integration, production and marketing of goods and services [16]. All commodity markets with large proportion of foreign trade operations belong to the category «world». For example global tin market, where export quota reaches $90 \%$ of its production, and those where it is 30-50\% moderate (car market) and small - 10-20\% [5]. Global market eliminates segmentation of national and territorial distribution of goods and creates market segmentation [17]. The globalization of markets and capital created new infrastructure - the structure of the world economy, the global organization of life and total regional communities has been formed in it [8]. International economic relations are realized through their agents. The subject

Free conjunctival pricing means that the price is influenced by supply and demand on market conditions. It is possible in conditions of perfect competition and the limited role of the state. If there is monopolistic and oligopolistic competition, the manufacturer dictates the price, but the state should thus regulate market processes on pricing and buying and sales (it is a natural monopoly, as other forms of monopolistic structures should not be characteristic of market economies). The state's role should be to create an enabling economic, political and legal environment for the development of the market system, the formation of collateral prices of strategic products to fill the state reserve with these products. Freedom of choice denotes freedom to choose both consumers and buyers in the buying and selling of products corresponding price and quality at a given time in a defined territory. Limited resources, used in the production of goods, works and services are an important aspect for market. It causes the necessity of the development of concepts of resource conservation and management of economic potential.

Changing the approach to the interpretation of the category of «market» has been caused by the influence of globalization on the economic processes in the world. The market is an integral part of the global environ- of the global market is an international organization of the state (legislative and executive), transnational corporations (TNCs), transnational banks (TNBs), producers associations, individuals and others. The peculiarity of the system of international economic relations is that not only the state is a regulator of relationships. Moreover, international organizations perform regulatory functions at the supranational level as opposed to public bodies and have a great influence on the development of international relations, since they involve regulatory process in many states [18]. Global market segmentation is important for producers. It is the process of identifying specific segments of potential customers as a group of individual or groups of customers with similar characteristics that show most probably similar behavior when buying [19]. The global economy is a collection of national economies associated with each system of international division of labor (MPP), economic and political relations. The international economic relations exercise universal relationship between national economies [20].

The global economy is the new historical reality. Unlike the global economy, it is «able to work as a single system in real time across the entire planet» [8]. The global market economy provides more active competition, especially in 
developing countries. The policy of the country should be aimed at inclusion of the environmental component in all sectors. State policy should include structural ecologyoriented restructuring, formation of ecology and balanced investment policy priorities, improving the mechanisms of privatization, reform of property rights, the development of an appropriate system of tax credits, subsidies, trade tariffs, greening production and others [21].

Thus, we can offer the author's approach to the relationship of the concepts of «global», «world», «international», «foreign trade» in the context of their use in the market economy. In our opinion, the term «world» is used to describe the phenomena and processes that have the same vector, i. e. contribute to solving one or a small number of related tasks within the reach of most countries. Herewith individuality of countries is stored, policy of protection in each country plays an important role. Participants of world space are independent and can finish easily international relations. The definition of «international» is used if the phenomenon or process involves interaction with one or more states (as opposed to large-scale global coverage).

The economy, the markets and their segments, relationships, work, the environment, space may be global and international. The concept of «foreign trade» involves consideration of phenomena and processes that take place outside the country respect. This term is used together with the categories of «activities» and «relationship», scientific literature includes the term «foreign market», which means selling products outside the national market and establishes relevant business relationships. Global approach involves the many interrelated tasks, while integrating state as close as possible to each other. Termination of relations between states in a globalized economy will lead to a restructuring of the global environment, the imbalance between the elements of the market system. Thus, the global market is a system of deeper economic relations between the countries over the buying and selling of goods and services, which is in the territories of the States Parties exchange for a certain period of time on market economy principles, providing a balance of economic development of the countries participating in the global market environment.

Market is a complex economic category, which is the basis of a number of elements relating logical structure interaction scheme. These elements are structured, both independent and interrelated. The branch, in which there are market relations, reveals features that distinguish a market economic system to another. At the same time, we cannot assert that market systems are limited to sectoral characteristics, as national and interstate market is a set of inter-industry relations arising in connection with the operation of market laws and the nature of relationships that go beyond imaginary boundaries. Market is an economic cycle of goods, services, resources, costs and revenues that occurs in the interaction of the market based on the market mechanism, market pricing under the influence of the market environment.
Many factors influences the formation of the market environment, structure of the state, government, historical features, the mentality of the population, consumption culture, business ethics, climatic features and more. These factors are united in several groups: political, economic, organizational, managerial, natural, socio-cultural, international, the combination of which determines the dynamism, speed and quality of market relations (Fig. 2).

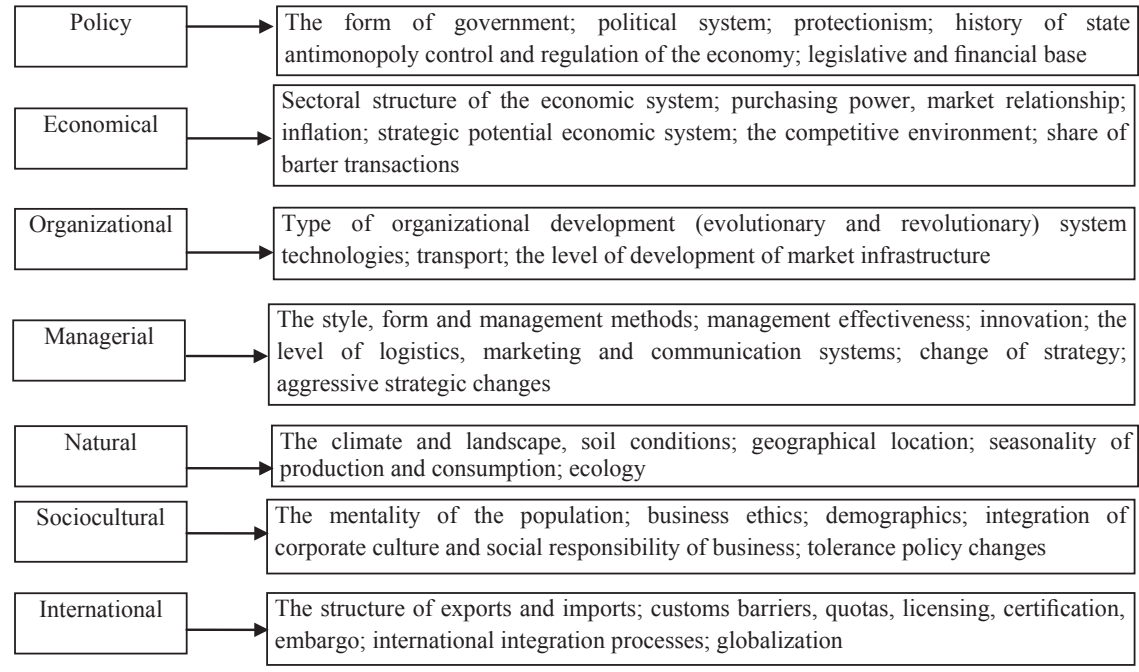
embargo; international integration processes; globalization is influenced by these factors. These groups of factors are interrelated and complementary, their weight and importance depend on the history and dynamics of economic development, variability environment of economic system. Thus, consideration of market model can identify six paradigms:

Paradigm 1. The market system is a set of relationships between subjects (agents) market over the production, processing and sale of goods (works, services) with limited resources for satisfaction of requirements of consumers.

Paradigm 2. The market as environment is interaction of favorable or deterrent elements that accompany the system subject-object relations.

Paradigm 3. The market as mechanism is a set and combination of methods and instruments regulating market system and enhancing its effectiveness.

Paradigm 4. The market as a process is a sequence of technological, organizational, economic, financial, political and other activities that accompany bringing goods (works, services) from producer to consumer.

Paradigm 5. The market as conjuncture is interrelation between supply and demand.

Paradigm 6. The market as chronology is a sequence of market operations in time and space.

Thus, the functioning of the market under current conditions is based on the interaction of various elements under the influence of several factors. The first level of relations is a system, it is formed by entities (agents) market, interacting in the production and sale of goods and services. The second level of relationship is opportunistic and is based on the market mechanism operations. The third level of relations occurs under domestic elements (macro environment) and global (mega environment). Consequently, the market is a three-level model, which 
is of particular forms of action based on industry factors. Basis of market functioning is six paradigms that are related.

\section{SWOT analysis of research results}

Strengths of the study is to obtain the most generalized models, namely «The concept of intersectoral scientific relations of category «market» and «The structure of the factors influencing on market environment». Also strong point is the formation of the definition «market» that is most adapted to current conditions of economic globalization.

Weaknesses in the research conducted are that set forth concepts and constructed models describe the market as a whole. If we look at different segments of the national market, it must take into account industry specific features.

Opportunities for further research are the construction industry conceptual models and study of the specific factors that determine the characteristics of these segments.

Threats to the survey results is that the market is dynamic; essence of the market, its structure and functions change under the influence of globalization, so research in this area should be carried out continuously.

\section{Conclusions}

1. The article is devoted to substantiation of new approaches to identify features of market in a globalized economy. It is proved that market is the multi-category, four main approaches should be used for understanding this category. Each of these approaches should be structured and divided into blocks:

1) political economy approach (economics, social economics, micro, macroeconomics, law, government regulation of the economy);

2) management paradigm (in its variations of: management potential, strategic, industrial, environmental management);

3) marketing and logistics approach (marketing, logistics, information);

4) approach in terms of intellectual property and business (intellectual property, business potential).

2. Global approach involves solution of the many interrelated tasks, while the countries integration as close as possible to each other. Termination of relations between states in a globalized economy will lead to a restructuring of the global environment, the imbalance between the elements of the market system.

3. The global market is a system of deep economic relations between the countries over the sale of goods and services that occur in the territories of all states - parties exchange on a certain period of time on market economy principles, providing a balance of economic development of member countries of the global market environment.

4. Market is a complex economic category, which basis consists of many elements related in structural and logical scheme of interaction. These elements are structured, both independent and interrelated. Industry is the dominant factor in the formation of the market system.

\section{References}

1. Dolan, E. G. Microeconomics [Text] / E. G. Dolan, D. E. Lindsey. - Dryden Press, 1994. - 500 p.
2. McConnell, C. R. Economics: Principles, Problems and Policies [Text] / C. R. McConnell, S. L. Brue, S. M. Flynn. Ed. 19. - McGraw-Hill Education, 2011. - 896 p.

3. Marshall, A. Principles of Economics [Text] / A. Marshall. Arkose Press, 2015. - 866 p.

4. Bashnianin, G. I. Ekonomicheskie sistemy [Text]: Monograph / ed. by G. I. Bashnianin. - Lvov: Liga-Press, 2013. - Vol. 4. 508 p.

5. Baturina, M. Rynok: sutnist, osnovni poniattia i struktura [Text]/ M. Baturina, V. Lukov. - Kyiv, 2005. - 384 p.

6. Biletska, L. V. Ekonomichna teoriia (Politekonomiia. Mikroekonmoika, Makroekonomika) [Text] / L. V. Biletska, O. V. Biletskyi, V. I. Savych. - Ed. 2. - Kyiv: Tsentr uchbovoi literatury, 2009. - 688 p.

7. Esposo Guerrero, B. J. Politics, Globalization, and Food Crisis Discourse [Text] / B. J. Esposo Guerrero // Economics Discussion Papers. - 2010. - № 22. - 17 p. doi:10.2139/ssrn.1726779

8. Castells, M. The Information Age, Volumes 1-3: Economy, Society and Culture [Text] / M. Castells. - Wiley-Blackwel, 1999. - 1488 p.

9. Federico, G. How much do we know about market integration in Europe? [Text] / G. Frederico // The Economic History Review. - 2012. - Vol. 65, № 2. - P. 470-497. doi:10.1111/ j.1468-0289.2011.00608.x

10. Fernandez, F. Modelling the Economic Impacts of Climate Change on Global and European Agriculture. Review of Economic Structural Approaches [Text] / F. Fernandez, M. Blanko // Economics: The Open-Access, Open-Assessment E-Journal. - 2015. № 9. - P. 1-53. doi:10.5018/economics-ejournal.ja.2015-10

11. Mbekeani, K. K. Infrastructure, trade expansion and regional integration: Global experience and lessons for Africa [Text] / K. K. Mbekeani // Journal of African Economies. - 2010. Vol. 19, Supplement 1. - P. 88-113. doi:10.1093/jae/ejp021

12. Samoilyk, Iu. V. Metodychni pidkhody do otsinky stratehichnoho potentsialu konkurentospromozhnosti pidpryiemstva [Text] / Iu. V. Samoilyk // Ekonomika APK. - 2012. - № 3. - P. 72-78.

13. Van Putten, I. E. Theories and behavioural drivers underlying fleet dynamics models [Text] / I. E. van Putten, S. Kulmala, O. Thévaud, N. Dowling, K. G. Hamon, T. Hutton, S. Pascoe // Fish and Fisheries. - 2011. - Vol. 13, № 2. - P. 216-235. doi:10.1111/j.1467-2979.2011.00430.x

14. Wier, M. The character of demand in mature organic food markets: Great Britain and Denmark compared [Text] / M. Wier // Food Policy. - 2008. - Vol. 3, № 5. - P. 406-421. doi:10.1016/ j.foodpol.2008.01.002

15. Nikolenko, Yu. V. Osnovy ekonomichnoi teorii [Electronic resource] / Yu. V. Nikolenko. - Kyiv: TsUL, 2003. - 540 p. Available at: \www/URL: http://www.ebk.net.ua/Book/OsnEkTeor/Oet06-09/5601.htm

16. Kayryak, O. World Market [Text] / O. Kayryak, O. Gamuga // Ekonomichni nauky. Ser.: Oblik i finansy. - 2012. - Vol. 9, № 2. - P. 9-13.

17. Boblovskyi, O. Trans-cultural Interaction in the Terms of Globalization [Text] / O. Boblovskyi // Visnyk Kharkivskoho natsionalnoho universytetu imeni V. N. Karazina. Seriia: Teoriia kultury i filosofiia nauky. - 2012. - № 995. - P. 49-53.

18. Maistro, S. V. Osoblyvosti rozvytku natsionalnoi ekonomiky v umovakh hlobalizatsii [Text] / S. V. Maistro, R. H. Maistro // Visnyk NTU «KhPI»: Tekhnichnyi prohres ta efektyvnist vyrobnytstva. - 2009. - Vol. 36, № 1. - P. 76-82.

19. Miazina, N. B. Dotsilnist sehmentuvannia hlobalnoho rynku silskohospodarskoi produktsii [Text] / N. B. Miazina // Formuvannia rynkovoi ekonomiky. - 2010. - № 24. - P. 336-344.

20. Grygorjev, O. Yu. Global economy and Ukraine [Text] / O. Yu. Grygorjev, V. V. Bojar, I. V. Malakhova // Visnyk Natsionalnoho universytetu «Lvivska politekhnika». Menedzhment ta pidpryiemnytstvo v Ukraini: etapy stanovlennia i problemy rozvytku. - 2013. - № 776. - P. 364-369. 
21. Inozemtsev, M. M. The competitiveness of crop production and its ecological and economic support [Text] / M. M. Inozemtsev // Rozvytok yevropeiskoho prostoru ochyma molodi: ekonomichni, sotsialni ta pravovi aspekty: materialy Vseukr. nauk.-prakt. konf. molodykh uchenykh ta studentiv, 22 kvitnia 2016 roku. - Kharkiv: NTMT, 2016. - P. 533-537.

\section{УСОВЕРШЕНСТВОВАНИЕ НАУЧНО-КОНЦЕПТУАЛЬНЫХ ПАРАДИГМ} РАЗВИТИЯ РЫККА В УСЛОВИЯХ ГЛОБАЛИЗАЦИИ ЗКОНОМИКИ

Построена концептуальная модель межотраслевых научных связей категории «рынок», для построения которой использованы четыре основных подхода: политэкономический, управлен- ческий, маркетингово-логистический и подход с точки зрения интеллектуальной собственности и бизнеса. Выявлены различия между терминами «международный», «мировой», «глобальный», «внешнеэкономический». Построена модель структуры факторов, влияющих на рыночную среду.

ключевые слова: межотраслевые научные связи, концептуальная модель, глобализация экономики, факторы рыночной среды.

Samoilyk Iuliia, PhD, Associate Professor, Department of Economic of Enterprise, Poltava State Agrarian Academy, Ukraine, e-mail: julija_s84@mail.ru,ORCID http://orcid.org/0000-0003-1335-2331

\section{Stechyshyn T.}

\section{RESEARCH OF MODERN MONETARY POLICY TRENDS: WORLD REALITY AND PROSPECTS FOR UKRAINE}

Визначено теоретичні аспекти застосування монетарного інструментарію як гнучкого механізму регулювання економіки. Проведено комплексний аналіз використання монетарних інструментів Федеральною резервною системою США. Проаналізовано дієвість антикризового монетарного регулювання Свропейського центрального банку та застосування інструментів монетарної політики ЄЦБ у посткризовий період. Окреслено перспективи впровадження рачіональних заходів монетарної політики в Украйні та особливості їх реалізації із врахуванням досвіду ЄС.

Ключові слова: монетарна політика, монетарне регулювання, антикризові інструменти, політика монетарного розширення, політика кількісного пом'якшення.

\section{Introduction}

Monetary policy of any state is an effective instrument for regulating and promoting economic growth of the state, contributing to the revitalization of economic entities activity and production development. However, the new practice of state regulation of the economy shows that monetary factors not only most affect to economic development, but also lead to strengthen the general instability in the economy, thereby increasing attention to various aspects of monetary policy. In scientific publications, authors explore the historical facts of monetary instruments, studying economic theory to explain the advantages of the classical proceedings of monetary policy.

\section{The object of research and its technological audit}

The object of the research is monetary policy as an effective tool for macroeconomic stabilization in Ukraine which is reflected in the use of different kinds of instruments to the rules and principles. Therefore, to develop proposals to enhance investment in the real economy a review of monetary policy leading European countries and the USA was done. It is found that the most effective anti-crisis and Stimulating policies was quantitative easing policy, used in the US and the policy of «special liquidity scheme» introduced by the Bank of England. The main common features of anti-crisis measures to stimulate investment activity was clearing banks from «toxic» assets and reducing interest rates. We consider it appropriate to apply the principles of quantitative easing in Ukraine adapting them to the realities of the present and the Ukrainian mentality, by implementing a clear and transparent mechanism to use make it impossible corruption schemes.

\section{The aim and objectives of research}

The main aim of the article is to discuss the international aspects of modern monetary policy and study the mechanism of formation of monetary instruments to stimulate banking investment to real sector, taking into account global monetary regulation trends of the economy.

To achieve this aim, the following scientific research tasks are:

1. To determine the theoretical aspects of monetary instruments as a flexible regulating mechanism to the economy.

2. To conduct a comprehensive analysis of using of the monetary tools by the Federal Reserve System of the USA.

3. To analyze the effectiveness of anti-crisis monetary regulation of the European Central Bank and the use of monetary policy instruments of the ECB in the post-crisis period.

4. To outline the prospects of implementation of rational measures of monetary policy in Ukraine and specifics of their implementation, taking into account the experience of the EU. 